\title{
Helsesøsters utfordringer med psykisk uhelse i skolen
}

\author{
Helsesøstre i skolen bruker mer enn halvparten av tiden sin på elever med psykiske plager. Hvordan \\ opplever de hverdagen sin? Og hvordan kan de bli bedre rustet til å hjelpe ungdommer som sliter?
}

\author{
FORFATTERE \\ $\varnothing$ yfrid Larsen Moen \\ Førsteamanuensis \\ Institutt for helsevitenskap, NTNU Gjøvik
}

\section{NøKKELORD}

Psykisk helse, Ungdom, Skole, Helsesøster

\section{HOVEDBUDSKAP}

Helsesøstre beskriver i denne studien at de bruker mer enn halvparten av sin arbeidstid i skolen på elever med psykiske plager.Helsesøstre som fagpersoner for ungdom i skolen - etterspør verktøy og kurs i psykisk helse. De ønsker også mer støtte fra barne- og ungdomspsykiatrien for å styrke arbeidet mot denne elevgruppen. En ny veileder anbefaler sterkt at helsesøstre i skolehelsetjenesten skal oppdage elever som har psykiske lidelser eller plager. Hvordan er de rustet til å møte dette kravet?

\section{BAKGRUNN}

Ettersom jeg har jobbet som helsesøster og forsker ble jeg nysgjerrig på hvordan helses $\varnothing$ stre i dag opplever å arbeide med elever i skolen som har psykiske plager. Jeg fikk med meg kollega Hege Kletthagen, som er psykiatrisk sykepleier, til å finne ut av dette. Vi foretok en spørreunders $\varnothing$ kelse blant helsesøstre som arbeider i skolen med elever mellom 11 og 18 år.

Via spørreskjemaer fikk vi besvarelse fra 284 helsesøstre fra 163 små og store kommuner i Norge. Vi brukte beskrivende og sammenliknende statistikk for å analysere resultatene (1). Spørreskjemaet hadde også noen åpne spørsmål hvor vi fikk utsagn fra helsesøstrene. Disse utsagnene ble analysert med kvalitativ innholdsanalyse (2).

Majoriteten hadde videreutdanning som helsesøster. 31 prosent hadde i tillegg videreutdanning innen psykiatri. Mange hadde også andre kurs innen psykisk helse. Spredning i ansiennitet var fra nyutdannet til 40 års erfaring. Alle respondentene var kvinner.

\section{KOMPLEKST BILDE}

Helsesøstrene opplevde at de møtte flere ungdommer med psykiske plager nå enn for fem år siden. Én helsesøster uttrykte det slik «Generelt er det viktig å poengtere at majoriteten av elevene har det bra, er tilfreds med lærerne sine og skolen generelt». Likevel viser forskning at om lag 20 prosent av alle ungdommer sliter med psykiske plager som angst og depresjon. Det gjelder spesielt jenter (3). 
Flere studier viser til at jenter er mer sårbare i forhold til stress, har lavere selvbilde og mer angst- og depresjonssymptomer enn gutter (4). Helsesøstrene i gjeldende studie beskrev også at de møtte mange ungdommer med slike plager. De beskrev også at elever sliter med rus, søvnproblemer og selvskading og at noen har selvmordstanker.

Andre elever har problemer knyttet til sosiale relasjoner og for eksempel foreldre som skilles. Psykiske plager henger ofte sammen med atferdsproblemer, problemer med venner og skoleprestasjoner $(5,6)$.

Det er et komplekst bilde helsesøstrene arbeider med i det daglige. Helsesøstre skal primært jobbe helsefremmende og forebyggende. Den nye veilederen til skolehelsetjenesten har en sterk anbefaling om at helsesøstre skal fange opp dem som har psykiske plager. Hvordan dette skal gjøres, er lite konkret beskrevet.

\section{TILGJENGELIGHET}

Helsesøstrene la vekt på at de må være tilgjengelige for ungdommene. Over 60 prosent av helsesøstrene beskrev at de bruker mer enn halvparten av tiden sin på ungdommer med psykiske plager. De opplevde denne delen av jobben som givende, men vanskelig.

Å ha en åpen dør er viktig, men mye av tiden består av rutinearbeid. Andre har ikke et kontor som er tilgjengelig eller egnet for samtaler. Helsesøstres tilgjengelighet er beskrevet $\mathrm{i}$ en studie hvor svært få av norske kommuner tilfredsstiller normtallene for stillinger i skolehelsetjenesten (7).

\section{«Helses $\varnothing$ ster er kanskje en av dem som ungdommer tør henvende seg til.»}

Helsesøster er kanskje en av dem som ungdommene tør å henvende seg til om vanskelige forhold i livet (8). Tilgjengelighet handler også om å være synlig og ha en åpen dør. En problemstilling kan også være at når helsesøster praktiserer åpen dør, kan også tilgjengeligheten bli begrenset ved at hun er opptatt.

Ungdom med psykiske plager har i en annen studie beskrevet at helsesøsters kontor var så bortgjemt og at helsesøster var så lite synlig, at de syntes det var vanskelig å oppsøke ham/henne (9).

\section{EGEN KOMPETANSE}

Helsesøstrene etterspurte spesielt opplæring og veiledning knyttet til arbeidet med ungdommer med psykiske plager. Av opplæring var enkle intervensjoner og vurderinger av ungdommers psykiske helse vurdert som viktigst.

Helsesøstre anvender ulike forskningsbaserte intervensjoner (10), som individ -og familiestøttende samtaler (11), skolebaserte programmer på gruppenivå (12) eller opplæring om psykisk helse av hele elevgruppen (13). Eller intervensjoner som blir gjennomført av miljøarbeider i skolen som gjennomføres i Arendal kommune hvor elever i videregående 
med depresjon, lærer å mestre depresjon (14).

Flere nyttige intervensjoner som ble beskrevet av helsesøstrene som deltok i studien var kurs i depresjonsmestring (KID), depresjonsmestring for ungdom (DU), psykologisk førstehjelp og mestringskatten. Ingen av disse intervensjonene er standardiserte og slik vil tilbudet i ulike kommuner i landet variere kraftig.

\section{STYRKE KVALITETEN}

Kjennskap til ulike intervensjoner avhenger derfor av kurs eller videreutdanning i psykisk helse. Det er kanskje en av grunnene til helsesøstrene, i denne studien, som nettopp hadde en videreutdanning eller kurs i psykisk helse, i mindre grad etterspurte enklere intervensjoner enn andre helsesøstre. De hadde lært om disse i sin videreutdanning eller på kurs.

Vi kan spørre oss om helsesøsterutdanningen er endret slik at den møter dagens samfunnsendring med mer plager i ungdomsgruppa. På den annen side hadde mange av dem som deltok i studien jobbet lenge som helsesøster, noen opp mot 40 år. Dermed kan kurs i psykisk helse - med fokus på enkle intervensjoner og vurderinger - kanskje kan være en av løsningene for å styrke helsesøstrene og deres kompetanse.

En standardisering av tilnærminger både på gruppe- og individnivå kan styrke kvaliteten på den tjenesten som gis.

\section{EN PROFESJONELL GUIDE}

De med videreutdanning i psykisk helse viste også at de var faglig tryggere på når de måtte henvise ungdom til annet helsepersonell. Vurderinger rundt hvem som bør henvises og hvem helsesøster kan ha ansvaret for videre, ble dermed mindre ved mer utdanning innen psykisk helse.

I følge WHO trenger ikke alle intervensjoner å bli utført av en spesialist i psykisk helse (15). Mange av disse ungdommene trenger en profesjonell voksenperson som kan guide dem gjennom de utfordringene som følger ungdomstiden.

En av helsesøstrene beskrev det slik: «Det er viktig å bruke ressurser på å forsikre seg om at ungdom kan håndtere stress og press som er en del av livet». Helsesøstrene hadde også tro på at de kunne være en betydningsfull person som kan støtte elever med psykiske plager.

\section{TAUS KUNNSKAP}

Andre har større psykiske plager og trenger oppfølging hos psykolog eller psykiater. Flere helsesøstre trenger å bli mer faglig robuste i denne delen av sitt arbeid. Enkle intervensjoner som styrker helsesøstrene i sitt arbeid uten at de trenger videreutdanning i psykisk helse, er på sin plass. En helsesøster sa: «Det er vanskelig for noen ungdommer å sette ord på det de synes er vanskelig - så vi trenger noen verktøy for å hjelpe dem til å få satt ord på følelsene».

Mange av helses $\varnothing$ strene i denne studien hadde lang erfaring, og erfaring genererer taus kunnskap (16). Så hvordan få gjort til kjenne den tause kunnskapen? Helsesøstrene etterspurte veiledning. Her kan de med lang erfaring dele sine kunnskaper og artikulere den tause kunnskapen. Sammen kan de reflektere og lære av hverandre. Om veiledningen blir gitt av spesialisthelsetjenesten, kan kunnskapsutvekslingen bli enda bedre.

\section{OPPLEVELSEN AV SAMARBEID}

Samarbeid med lærere ble sett på som personavhengig, avhengig av om læreren anså engasjement og kunnskap om psykisk helse som viktig. Det blir beskrevet som vanskelig for 
helsesøster å overbevise læreren om at den tiden eleven tilbrakte sammen med helsesøster var vel anvendt tid for å forebygge psykiske plager. Men helsesøstrene må også vise sin kompetanse i samarbeid med andre yrkesgrupper da de tradisjonelt sett har hatt fokus på fysisk utvikling og helse (17).

\section{«En helhetlig tilnærming og forståelse er helsesøstrenes styrke.»}

På en annen side viser det seg at ungdom henvender seg til helsesøster med fysiske plager som kan brukes som inngangsport for å snakke om eventuelle psykiske plager $(11,18)$. En helhetlig tilnærming og forståelse - som er helsesøstrenes styrke, fremfor de med spesialisert kunnskap i for eksempel psykisk helse - kan være grunnen til at hun/han er en av de første ungdommene henvender seg til.

\section{RETNINGSLINJER}

Helsesøstrene etterspurte retningslinjer og krav til samarbeid mellom helsesøster og lærer. Én helsesøster sa: «Vi skulle hatt mer tid til kunnskapsutveksling i arbeidet knyttet til elever med psykiske plager». Kunnskapsutvekslingen trenger ikke å gå på bekostning av taushetsplikten, understrekte flere.

Samarbeid med fastlegen ble også problematisert. Ikke fordi fastlegen eller helses $\varnothing$ ster ikke $\emptyset$ nsket samarbeid, men grunnet fastlegens kapasitet med hensyn til pasienter og tid til rådighet. Helsesøstrene beskrev at de sjelden ble invitert til samarbeid med fastlegen selv om de jobbet med de samme ungdommene. Dette er bekreftet i andre studier $(19,20)$.

Selv om helsesøster tok kontakt med fastlegen og initierte videre utredning eller oppfølging fra spesialisthelsetjenesten, fikk ikke helsesøster epikrisen rutinemessig etter spesialistvurderingen. Dette gjorde oppfølgingen av eleven vanskelig, selv om det var nettopp helsesøster som satt med oppfølgingen og mange rapporterte at de sto mye alene i oppfølgingen av elever med psykiske plager.

\section{VIKTIG ROLLE}

Helsesøster er en viktig og godt plassert fagperson i møte med ungdommer. Slik sett er de godt egnet til å avdekke om noen har psykiske plager eller lidelser. Men for å kunne utnytte sitt potensial må helsesøster få veiledning, tilstrekkelig kunnskap, riktige verktøy og tilpassete intervensjoner for å være trygg i sin rolle.

Utarbeidelse av nasjonale retningslinjer og standardiserte verktøy og intervensjoner kan bidra til mer likhet i tjenesten på tvers i landet. Det bør forskes videre på enkle intervensjoner og «verktøy» som er anvendbare i helsesøsters praksis i skolehelsetjenesten.

Denne artikkelen bygger på en studie som er publisert i to artikler:

Moen, $\varnothing \mathrm{L}$, Skundberg-Kletthagen, H. Public health nurses' experience, involvement and attitude concerning mental health issues in a school setting. Nordic Journal of Nursing 
Skundberg-Kletthagen, $\mathrm{H}$, Moen, $\varnothing \mathrm{L}$. Mental health work in school health services and school nurses' involvement and attitudes, in a Norwegian context. Journal of Clinical Nursing.

2017;26:5044-51. DOI:10.1111/jocn.14004

\section{REFERANSER}

1. Field A. Discovering statistics using IBM SPSS statistics: and sex and drugs and rock ' $n$ ' roll. Los Angeles: SAGE; 2013.

2. Elo $S$, Kyngäs $H$. The qualitative content analysis process. Journal of Advanced Nursing. 2008;62(1):107-15.

3. Kieling C, Baker-Henningham H, Belfer M, Conti G, Ertem I, Omigbodun O, et al. Child and adolescent mental health worldwide: evidence for action. The Lancet.

2011;378(9801):1515-25.

4. Moksnes UK, Løhre A, Lillefjell M, Byrne DG, Haugan G. The association between school stress, life satisfaction and depressive symptoms in adolescents: Life satisfaction as a potential mediator. Social Indicators Research. 2016;125(1):339-57.

5. Nordfeldt S, Arvidsson E, Bernfort L. Sjukvårdens och skolans insatser för barn med AD/HD-föräldrars erfarenheter. Linköping: Linköpings universitet; 2006.

6. Bremberg S, Dalman C. A knowledge: Concepts, measurement methods and prevalence of mental health, mental illness and psychiatric disorders in children and adolescents. (En kunskapsöversikt: Begrepp, mätmetoder och förekomst av psykisk hälsa, psykisk ohälsa och psykiatriska tillstånd hos barn och unga). Stockholm. Forte; 2015.

7. Waldum-Grevbo KS, Haugland T. A survey of school nurse staffing in the school health services. Sykepleien Forskning. 2015;10(4).

8. Larsson M, Björk M, Ekebergh M, Sundler AJ. Striving to Make a Positive Difference. The Journal of School Nursing. 2014;30(5):358-65.

9. Steffenak AKM, Wilde-Larsson B, Hartz I, Nordström G. Experience of psychotropic drug use among young people with mental health problems. Nordic Journal of Nursing Research. 2015;35(4):241-8.

10.Dahl BM, Clancy A. Meanings of knowledge and identity in public health nursing in a time of transition: interpretations of public health nurses' narratives. Scandinavian journal of caring sciences. 2015;29(4):679-87.

11. Clausson E, Berg A. Family Intervention Sessions One Useful Way to Improve Schoolchildren's Mental Health. Journal of family nursing. 2008;14(3):289-313.

12. Garmy P, Jakobsson U, Carlsson KS, Berg A, Clausson EK. Evaluation of a School-Based Program Aimed at Preventing Depressive Symptoms in Adolescents. The Journal of School Nursing. 2015;31(2):117-25.

13. Bjørnsen HN, Espnes GA, Eilertsen M-EB, Ringdal R, Moksnes UK. The Relationship Between Positive Mental Health Literacy and Mental Well-Being Among Adolescents: Implications for School Health Services. The Journal of School Nursing.2017 Tilgjengelig fra: 
http://journals.sagepub.com/doi/abs/10.1177/1059840517732125 (nedlastet 11.12.2017).

14. Ottersland B. Lærer å mestre depresjon. Tidsskrift for Helsesøstre. 2017;17(01):62-4.

15. WHO. Adolescents and mental health 2017 Tilgjengelig fra: http://www.who.int/maternal_child_adolescent/topics/adolescence/mental_h... (nedlastet 11.12.2017).

16. Clancy A, Svensson T. Perceptions of public health nursing consultations: Tacit understanding of the importance of relationships. Primary Health Care Research \& Development. 2010;11(4):363-73.

17. Ministry of Health and Care Services. Municipalities Health Promotion and Prevention in Health Clinics and School Health Services. (Kommunenes helsefremmende og forebyggende arbeid i helsestasjons- og skolehelsetjenesten. Veileder til forskrift av 3. april $2003 \mathrm{nr} 450$ ). Oslo2003. s.1-68.

18. Puskar KR, Bernardo LM. Mental Health and Academic Achievement: Role of School Nurses. Journal for Specialists in Pediatric Nursing. 2007;12(4):215-23.

19. Steffenak AKM, Nordström G, Hartz I, Wilde-Larsson B. Public health nurses' perception of their roles in relation to psychotropic drug use by adolescents: a phenomenographic study. Journal of Clinical Nursing. 2015;24(7-8):970-9.

20. Moen $\varnothing$ L, Hedelin B, Hall?Lord ML. Public health nurses' conceptions of their role related to families with a child having Attention?deficit/hyperactivity disorder. Scandinavian journal of caring sciences. 2014;28(3):515-22. 